\title{
Factors of effective strategy implementation: Empirical evidence from Slovenian business practice*
}

\author{
Tomaž Čater, Danijel Pučko**
}

The paper's purpose is to add to the body of knowledge on strategy implementation by systematically studying the activities for and obstacles to strategy execution on a sample of 172 Slovenian companies. The results show that managers mostly rely on planning and organising activities when implementing strategies, while the biggest obstacle to strategy execution is poor leadership. Moreover, the results of multiple regression analysis reveal that greater obstacles to strategy execution in the forms of inadequate leadership skills and employees' reluctance to share their knowledge have a negative influence on performance, while adapting the organisational structure to the selected strategy as an activity for strategy implementation has a positive influence on performance.

Der Zweck dieses Artikels ist, einen Beitrag zur Erweiterung des Wissens über Aktivitäten und die Hindernisse der Strategiedurchführung beizutragen anhand eines Samples von 172 Slowenischen Unternehmen. Die Ergebnisse zeigen, dass sich die Betriebsleiter bei der Implementation von Strategien größtenteils auf Planung und Organisaiton konzentrieren, während das größten Hindernis zur Durchführung der Strategie schlechte Führung ist. Weiter zeigen die Ergebisse der Multiplen Regression auf, dass Hindernisse zur Strategiedurchführung in Form von mangelhafter Fürung und der Zurückhaltung der Mitarbeitern, ihre Kenntnisse mitzuteilen, einen negativen Einfluss auf den Erfolg haben, während die Anpassung der Organisationsstruktur an die ausgewählte Strategie einen positiven Einfluss auf den Erfolg hat.

Key words: strategy, strategy implementation, activity, obstacle, performance, Slovenia

* Manuscript received: 22.11.08, accepted: 21.10 .09 (1 revision)

** Tomaž. Čater, Ph.D., Associate Prof., Department of Management and Organisation, University of Ljubjana, Slovenia. Main research areas: Corporate and business strategies, competitive advantage, business relationship and environmental strategies. Corresponding address: Tomaz.cater@ef.uni-lj.si.

Danijel Pučko, Ph.D., Prof., Faculty of Economics, University of Ljubjana, Slovenia. Main research areas: Strategic planning and strategy implementation, annual planning and control and business analysis. Corresponding address: danijel.pucko@ef.uni-lj.si. 


\section{Introduction}

One of the main reasons for the emergence of strategic management in the last quarter of the 20th century was to pay proper attention to the implementation of strategy in companies. There is no doubt that strategic planning is important yet formulated strategies must also be implemented otherwise the whole planning phase becomes worthless. The planning-implementation relationship is well described by Hrebiniak (2005b:4), one of the most prominent authors in the field of strategy implementation: "It is obvious that the execution of strategy is not merely as clear and understood as the formulation of strategy. Much more is known about planning than doing, about strategy making than making strategy work".

Hrebiniak's (2006/2008) argument that, while formulating a strategy is hard, making it work, i.e. "executing or implementing it throughout the organisation", is even harder, is supported by past empirical studies which report weak relationships between strategy formulation and its implementation. Fortune magazine (Gurowitz 2007) finds that less than 10\% of well-formulated strategies are also effectively executed. Identical results of just $10 \%$ of strategies being successfully implemented are also reported by Judson (1991) and Speculand (2006). Similarly, a Times' (Farsight Leadership Organisation 2007) study finds that $80 \%$ of companies have the right strategies, yet only $14 \%$ implement them well. A 2003 survey by the Economist Intelligence Unit and Makaron Associates (Mankins/Steele 2005) reports slightly better but still very disappointing achievements, discovering that on average companies deliver a mere $63 \%$ of the potential financial performance their strategies have promised. As reported by Raps (2004), a conclusion can be made that the real success rate of strategy implementation lies between 10 and 30\%. Therefore, most companies have strategies but only a few actually realise them. These low success rates are discouraging, especially since many companies recently have invested huge sums of money to improve their strategic planning (Raps 2004). At the end of the 20th century US companies were, for example, spending more than USD 10 billion annually in analysing their industries, markets and competitors, and then formulating their strategic plans (Judson 1991). In addition to the enormous waste of money involved, the low success rates of strategy implementation processes are also problematic because poor strategy implementation weakens the subsequent planning cycle (Crittenden/Crittenden 2008). Such deficient strategy implementation therefore inhibits future strategy formulation which creates a deadly spiral of two mutually enforcing factors poor planning and poor implementation.

The presented empirical findings on strategy implementation are therefore far from encouraging. The introduction of strategic management as we know it today (i.e. the process of strategic planning combined with strategy implementation and control) opened up a formal framework for dealing with this 
problem, yet to date it has not attracted much academic attention (Gottschalk 2008). Noble (1999), for example, argues that we are still witnessing a noticeable absence of a deep and cohesive body of literature in the field of strategy implementation. Of course, this must have consequences for business practice. Hrebiniak (2006) argues that most managers know far more about developing strategy than they do about executing it. As a result, they spend a lot of time formulating their strategies but often find that almost nothing ultimately changes in their companies. The original momentum somehow disappears before the company can realise the expected benefits (Pellegrinelli/Bowman 1994). To overcome these huge problems of strategy implementation, many authors (Connor 2001) call for researchers to more strongly emphasise the practical problems of strategy implementation.

Taking into account the poor level of knowledge in the field of strategy implementation in general and keeping in mind that serious empirical research about the factors of strategy implementation in Central and South-east Europe has been almost completely neglected, we intend to contribute to the development of this field by providing relevant insights into a number of issues linked with strategy implementation. More specifically, the purpose of this paper is to add to the body of knowledge on strategy implementation by studying the activities for strategy implementation and obstacles to strategy implementation faced by Slovenian ${ }^{1}$ companies. Although these two issues (activities and obstacles) have been addressed in past research (e.g. Alexander 1985; Hauc/Kovač 2000; Heintz 2002; Hrebiniak 2005b; Brenes et al. 2008), they have not been addressed simultaneously. The value of this study can therefore be especially found in its combined investigation of both activities for and obstacles to strategy implementation. In particular, the research offers value by systematically addressing the following research questions: (1) What are the most important groups of activities for and obstacles to strategy implementation? (2) How do companies from different size, sector, ownership and sales market groups differ in the activities they practice and in the obstacles

1 Slovenia is a small country with a surface area of $20,256 \mathrm{~km} 2$ and slightly more than 2 million inhabitants. It has a unique strategic position in the heart of Europe, bordering with Italy to the west, Austria to the north, Hungary to the north-east, Croatia to the east and south and the Adriatic Sea to the south-west. Slovenia declared its independence from communist Yugoslavia in 1990. Its transition was relatively successful with relatively stable and fast GDP growth. The economic transition process was completed shortly before Slovenia became a full member of the European Union on 1 May 2004. The country has also been a full member of the European Monetary Union since 1 January 2007. Similarly to most parts of the world the consequences of the global financial and economic crisis can also be seen in Slovenia. As a consequence of being a small economy most Slovenian companies depend on foreign markets (mostly the most important European markets such as Germany), which means that a recession in export markets has a direct consequence for the sales of most Slovenian companies. 
they face when implementing their strategies? (3) What is the relationship between the activities for and obstacles to strategy implementation on one hand and company performance on the other?

To address these research questions systematically the paper is structured in five sections. After the introduction, Section 2 offers a literature review focusing on the activities for and obstacles to strategy implementation. In Section 3 we explain the empirical research approach by describing the questionnaire, sample, respondents and the way the survey was carried out. Section 4 describes the empirical findings, organised so as to provide answers to the abovementioned research questions. Finally, in Section 5 we present the concluding comments, discuss the implications and limitations of the study and suggest some directions for future research.

\section{Literature review}

\subsection{The essence of strategy implementation}

Regardless of the type and level of strategy, in the end managers are always "faced with the straightforward task of simply getting things done" (Hrebiniak 2005a:57). Strategy implementation is therefore concerned with putting strategy into practice and can be described as the execution of tactics so that the company moves in the desired strategic direction (Giles 1991). Similarly, strategy implementation can also be defined as the "relatively straightforward operationalisation of a clearly articulated strategic plan" (Noble 1999:119) or "the sum total of the activities and choices required for the execution of a strategic plan" (Wheelen/Hunger 2006:214). In this paper we therefore understand strategy implementation as a systematic process composed of a logical set of connected activities that enable a company to make a strategy work.

Noble (1999:119) describes the roots of the strategy implementation research as "eclectic". The traditional approach to strategy implementation treated strategy implementation as an activity following formulation. As such, the concept was treated primarily as a question of organisation design (Lorange (1982) was probably among the first to emphasise this), where systems and structures have to be aligned with strategic goals (Bourgeois/Brodwin 1984). More recent studies seem to be more structured and focus on two different but closely connected views of strategy implementation - the structural view and the interpersonal process view (Skivington/Daft 1991). While the former proposes that managers make adjustments to formal, structural elements of the organisation in order to enact strategic decisions, the latter deals with a range of interpersonal and cognitive factors that managers must also address to interpret and respond to a strategic initiative (Noble 1999). In addition, some authors propose even more specific divisions of the key areas of strategy implementation 
such as organisation, people, culture and control systems and instruments (Raps 2004).

\subsection{Activities for strategy implementation}

In an attempt to systematically structure the implementation process, several authors propose different models that companies should follow to be able to better implement their strategies. One of the first such models was offered by Hrebiniak and Joyce (1984), who argue that a well-articulated strategy is the first critical ingredient of the implementation process. This is then followed by the design of a primary organisational structure, establishing operating-level objectives, the design of operating structures and, finally, the creation of proper incentives and control mechanisms that support the implementation. In implementing strategies based on the described process companies therefore constantly switch between planning and organisational design, starting at the top organisational levels and then moving down to lower hierarchical levels. Most of the concepts included in Hrebiniak and Joyce's (1984) model also constitute models that have been proposed recently. Naturally, the recent models also include other concepts. Higgins (2005), for example, proposes a revision of McKinsey's original "7S" model and proposes an "8S" model (consisting of Strategy, Structure, Systems and processes, leadership Style, Staff, reSources, Shared values, and Strategic performance) to help managers better focus on strategy execution.

Along with the models representing the most important factors of strategy implementation, authors also investigate how the implementation of certain activities, which represent certain steps or tasks that need to be accomplished in the implementation process, influences strategy implementation and through that company performance. Based on an extensive literature review we identified 12 of the most commonly addressed strategy implementation activities that can be classified in four broad groups: planning, organising, leadership and controlling activities. These activities are listed in Table 1, where the most relevant references to past research are also given for each of them.

\subsection{Obstacles to strategy implementation}

Besides the activities that need to be accomplished if a company wants to implement its strategies, one should not neglect variables in the organisational context that could hinder or represent obstacles to effective strategy implementation. Hrebiniak (2005b) identifies four broad contextual factors that deserve special attention when discussing obstacles to strategy implementation: the change management context, the organisational culture context, the organisational power structure context and the leadership context. These four factors affect and are affected by each other. When all four are synchronised, the prognosis for effective strategy implementation should be very positive. 
Table 1. Overview of the most important activities for successful strategy implementation

\begin{tabular}{|c|c|c|}
\hline $\begin{array}{l}\text { Activity } \\
\text { group }\end{array}$ & $\begin{array}{l}\text { Activities as operationalised } \\
\text { in this study }\end{array}$ & Activities addressed in the literature \\
\hline \multirow{4}{*}{ 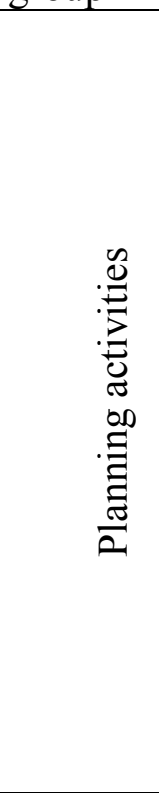 } & $\begin{array}{l}\text { Formulating and } \\
\text { implementing development } \\
\text { programmes }\end{array}$ & $\begin{array}{l}\text { Programming and budgeting (Pučko 2006) } \\
\text { Developing programmes, budgets and } \\
\text { procedures (Wheelen/Hunger 2006) }\end{array}$ \\
\hline & $\begin{array}{l}\text { Planning and implementing } \\
\text { projects }\end{array}$ & $\begin{array}{c}\text { Translating strategy into projects } \\
\text { (Pellegrinelli/Bowman 1994) } \\
\text { Managing projects (Kovač 1996; Grundy 1998; } \\
\text { Hauc/Kovač 2000; Minarro-Viseras et al. 2005; } \\
\text { Pučko 2006) }\end{array}$ \\
\hline & $\begin{array}{l}\text { Using an efficient annual } \\
\text { planning system }\end{array}$ & $\begin{array}{c}\text { Establishing operating-level objectives } \\
\text { (Hrebiniak/Joyce 1984) } \\
\text { Tactical (annual) planning (Pučko 2006) } \\
\text { Annual business planning (Birnbaum 2007) }\end{array}$ \\
\hline & Applying action planning & $\begin{array}{c}\text { Action planning (Pučko 2006; Wheelen/Hunger } \\
\text { 2006; Birnbaum 2007) } \\
\text { Turning strategy into action (Farsight } \\
\text { Leadership Organisation 2007) }\end{array}$ \\
\hline \multirow[t]{2}{*}{ 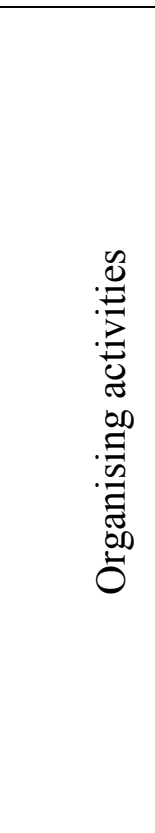 } & $\begin{array}{l}\text { Organising for strategy } \\
\text { implementation }\end{array}$ & $\begin{array}{c}\text { Fitting the organisation to the strategy } \\
\text { (organisation design) (Lorange 1982; Kovač } \\
1996 \text { ) } \\
\text { Designing a primary and operating } \\
\text { organisational structures (Hrebiniak/Joyce } \\
1984 \text { ) } \\
\text { Organising for strategy implementation (Pučko } \\
2006 \text { ) } \\
\text { Organising for action (Wheelen/Hunger 2006) } \\
\text { Developing organisational structure (Birnbaum } \\
\text { 2007) }\end{array}$ \\
\hline & $\begin{array}{l}\text { Allocating strict responsibility } \\
\text { for strategy implementation }\end{array}$ & $\begin{array}{l}\text { Translating enterprise-level plans into lower- } \\
\text { unit-level plans (Kaplan/Norton 2005) } \\
\text { Allocating responsibility for strategy } \\
\text { implementation (Pučko 2006) } \\
\text { Involving people from all organisational levels } \\
\text { (Wheelen/Hunger 2006) }\end{array}$ \\
\hline 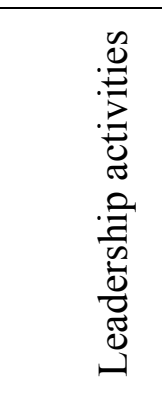 & $\begin{array}{l}\text { Using leadership to direct } \\
\text { employees }\end{array}$ & $\begin{array}{l}\text { Triggering enthusiasm in employees (Nichols } \\
\text { 1994) } \\
\text { Directing employees (Pučko 2006) } \\
\text { Leading by coaching people (Wheelen/Hunger } \\
\text { 2006) } \\
\text { Motivational leadership (Farsight Leadership } \\
\text { Organisation 2007) } \\
\text { Leading the change (Brenes et al. 2008) }\end{array}$ \\
\hline
\end{tabular}




\begin{tabular}{|c|c|c|}
\hline & Using formal communication & $\begin{array}{l}\text { Emphasising communication between all parties } \\
\text { (Al-Ghamdi 1998) } \\
\text { Communicating the corporate strategy } \\
\text { (Kaplan/Norton 2005) } \\
\text { Communicating strategy to people (Speculand } \\
\text { 2006) }\end{array}$ \\
\hline & $\begin{array}{c}\text { Applying MBO (management } \\
\text { by objectives) }\end{array}$ & $\begin{array}{l}\text { Aligning employees' goals with strategic goals } \\
\text { (Kaplan/Norton 2005) } \\
\text { Management by objectives (Pučko 2006; } \\
\text { Wheelen/Hunger 2006) }\end{array}$ \\
\hline & Applying HRM activities & $\begin{array}{c}\text { Executing HR activities (Fulmer 1990; Ulrich } \\
1998 \text { ) } \\
\text { Staffing (Pučko 2006; Wheelen/Hunger 2006) } \\
\text { Managing human resource factors (Birnbaum } \\
\text { 2007) }\end{array}$ \\
\hline \multirow{2}{*}{ 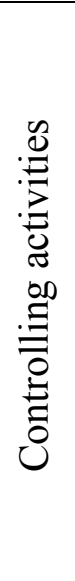 } & $\begin{array}{l}\text { Using an efficient tactical } \\
\text { control system }\end{array}$ & $\begin{array}{l}\text { Creating incentives and control mechanisms } \\
\text { (Hrebiniak/Joyce 1984) } \\
\text { Controlling the implementation of strategies } \\
\text { (Pučko 2006) } \\
\text { Monitoring and control (Birnbaum 2007) } \\
\text { Implementing control and follow-up actions } \\
\text { (Brenes et al. 2008) }\end{array}$ \\
\hline & $\begin{array}{l}\text { Applying the BSC (balanced } \\
\text { scorecard) }\end{array}$ & $\begin{array}{l}\text { Using the balanced scorecard (Kaplan/Norton } \\
1996,2006) \\
\text { Consistently measuring progress and } \\
\text { performance (Farsight Leadership Organisation } \\
\text { 2007) }\end{array}$ \\
\hline
\end{tabular}

Managing change is difficult but absolutely critical for successful strategy execution (Hrebiniak 2008). Wharton-Gartner's study (Hrebiniak 2005b) found that problems with change management constitute the single biggest threat to strategy implementation. Leaders must therefore identify areas of necessary change and overcome any potential resistance to change. They are instrumental in changing and managing key people, incentives and organisational structures.

Organisational culture refers to the shared values, attitudes and norms of behaviour that create the propensity for individuals in an organisation to act in certain ways. One of the most common culture-related problems in companies is a lack of trust (Hrebiniak 2005b), which usually results in poor or inadequate information and knowledge sharing between individuals and/or business units responsible for strategy implementation. This problem was, for example, ranked as one of the largest obstacles to strategy execution by American managers (Hrebiniak 2005b). Another common cultural problem is the domination of the short-term orientation in a company. Two independent studies conducted by Alexander (1985) and Al-Ghamdi (1998) report that competing short-term activities distract attention from strategy implementation in $64 \%$ and $83 \%$ of companies, respectively. 
The organisational power structure is important because it influences decisions regarding the allocation of all kinds of resources necessary for strategy execution. Hrebiniak (2005b, 2006) and Gurkov (2009) argue that even wellprepared and sound plans die if the implementers fail to confront difficult organisational and political obstacles that stand in the way of effective implementation. Therefore, strategy executors must persuade all relevant employees to carry out all activities necessary to implement the strategy (Hrebiniak 2005b). Obviously, the top manager's guidance, support and active involvement in strategy implementation is critical (Brenes et al. 2008). If those in power do not care about or even resist execution of the strategy, the success of the implementation process is clearly jeopardised (Hrebiniak 2005b).

Finally, proper leadership skills are also needed to ensure employees will execute the selected strategies. One of the biggest problems is usually the lack of co-ordination and clear guidelines (Hrebiniak 2005b). Al-Ghamdi (1998), for example, reports that $75 \%$ of companies lack the effective co-ordination of implementation activities. According to Kaplan and Norton (2006), this problem can be partly solved by using strategic maps which connect a strategy paper with an operative execution plan and can therefore substitute organising efforts for strategy implementation. Another important function of leadership is to "sell" the strategy to everyone who matters (Hambrick/Cannella 1989). A strategy must therefore be successfully communicated to the employees (Hrebiniak 2005b). Kaplan and Norton (2005) argue that on average 95\% of a company's employees are unaware of or do not understand the company's strategy. And if the employees are unaware of the strategy, they surely cannot help the company implement it effectively. Studies also confirm the success of the strategy execution depends on the adoption of a compensation system that motivates managers and employees to achieve company goals (Terborg/Ungson 1985).

In addition to the four organisational context variables one also should not forget that a strategy cannot be successfully implemented if the strategic planning, i.e. strategic analysis (Pučko/Čater 2008) and strategy formulation (Hrebiniak 2005b), is poor. In this regard, Giles (1991:76-77) argues there are three reasons why poor strategic planning is an obstacle to strategy implementation: (1) a strategy is not really a strategy but "a mixture of budgets and management wish list"; (2) a strategy is not executable; and (3) a strategy is not owned by the executors because they did not participate in its formulation and therefore do not accept it as "their own".

Based on the presented literature review, we identified 13 of the most commonly addressed obstacles to strategy implementation that can be classified in five broad groups: problems in strategy formulation, change management problems, organisational culture problems, problems related to organisational power structure and leadership problems. 
As shown in Table 2, most of the operationalisations of these obstacles are adapted from Hrebiniak's (2005b) contextual framework, while some are based on the work of other authors.

Although our paper follows Hrebiniak's (2005b) contextual framework in classifying obstacles to strategy implementation, it is worth mentioning here that some of these obstacles can have several common sources or interpretations. Baier et al. (1988:151) suggest two such general interpretations of strategy implementation problems.

Table 2. Overview of the most important obstacles to successful strategy implementation

\begin{tabular}{|c|c|c|}
\hline $\begin{array}{l}\text { Obstacle } \\
\text { group }\end{array}$ & Obstacles as operationalised in this study & Relevant references \\
\hline \multirow[b]{2}{*}{$\begin{array}{l}\text { Strategy } \\
\text { formulation }\end{array}$} & Strategic analysis is not properly conducted & Pučko/Čater 2008 \\
\hline & Strategy is poorly defined & $\begin{array}{c}\text { Giles 1991; Hrebiniak } \\
\text { 2005b }\end{array}$ \\
\hline $\begin{array}{l}\text { Change } \\
\text { management }\end{array}$ & $\begin{array}{l}\text { Managers lack capabilities to implement change } \\
\text { management }\end{array}$ & Hrebiniak 2005b, 2008 \\
\hline \multirow{3}{*}{$\begin{array}{l}\text { Organisation } \\
\text { al culture }\end{array}$} & $\begin{array}{l}\text { Managers do not trust information generated outside } \\
\text { their units }\end{array}$ & Hrebiniak 2005b \\
\hline & $\begin{array}{l}\text { Employees are reluctant to share knowledge with } \\
\text { colleagues }\end{array}$ & Hrebiniak 2005b \\
\hline & Short-range orientation dominates the company & $\begin{array}{l}\text { Alexander 1985; Al- } \\
\text { Ghamdi } 1998\end{array}$ \\
\hline \multirow{3}{*}{$\begin{array}{l}\text { Organisation } \\
\text { al power } \\
\text { structure }\end{array}$} & $\begin{array}{l}\text { Strategy conflicts with existing organisational } \\
\text { power structure }\end{array}$ & Hrebiniak 2005b, 2006 \\
\hline & $\begin{array}{c}\text { Managers lack ideas how to persuade employees to } \\
\text { execute the strategy }\end{array}$ & \begin{tabular}{|} 
Hrebiniak 2005b; Gurkov \\
2009 \\
\end{tabular} \\
\hline & $\begin{array}{c}\text { Top management is not actively engaged in } \\
\text { strategy implementation }\end{array}$ & $\begin{array}{l}\text { Hrebiniak 2005b; Brenes } \\
\text { et al. } 2008\end{array}$ \\
\hline \multirow{4}{*}{ Leadership } & $\begin{array}{c}\text { Managers lack leadership skills for strategy } \\
\text { implementation }\end{array}$ & Hrebiniak 2005b \\
\hline & $\begin{array}{l}\text { There are no guidelines or a model to guide } \\
\text { strategy execution efforts }\end{array}$ & $\begin{array}{c}\text { Al-Ghamdi 1998; } \\
\text { Hrebiniak 2005b; } \\
\text { Kaplan/Norton 2006 } \\
\end{array}$ \\
\hline & $\begin{array}{l}\text { Strategy is not properly communicated to lower } \\
\text { levels }\end{array}$ & $\begin{array}{c}\text { Hambrick/Cannella 1989; } \\
\text { Hrebiniak 2005b; } \\
\text { Kaplan/Norton 2005 } \\
\end{array}$ \\
\hline & $\begin{array}{l}\text { Reward systems do not stimulate strategy } \\
\text { implementation }\end{array}$ & Terborg/Ungson 1985 \\
\hline
\end{tabular}

The first relates to difficulties in implementation due to "bureaucratic incompetence", while the second is linked to difficulties in implementation due to a "conflict of interest" between policy-makers and strategy executors. The first common source of problems is therefore linked to more bureaucratic or technical difficulties (e.g. improper reward systems, improper strategic analysis, 
lack of guidelines to guide strategy execution efforts etc.), whereas the second one relates to more interpersonal issues (e.g. strategy conflicts with the existing power structure, employees are reluctant to share knowledge with colleagues, managers do not trust information generated outside their units etc.).

\section{Methodological background}

The research questionnaire was prepared by the authors taking into account the key factors of successful strategy implementation found in the literature. Above all, we consulted the questionnaire developed and used by Hrebiniak (2005b) in his empirical research ${ }^{2}$ The main part of the questionnaire included statements regarding the most important activities needed for strategy implementation and obstacles that hinder strategy implementation. For all the statements the respondents were asked to express their agreement with a given statement using a seven-point Likert-type scale. Besides these statements, the questionnaire also included questions about the use of the balanced scorecard, the company's return on equity (ROE) and some other data such as company size (measured by the number of employees), the industry in which the company operates, its ownership and its major sales markets. The questionnaire was tested on ten members of the population.

The population was defined as companies registered in Slovenia that had been active for at least five years. Data were gathered in May and June 2008 by sending questionnaires to Chief Executive Officers. 480 questionnaires were distributed and, by the end of the data gathering, 172 companies had answered the survey, meaning a response rate of $35.8 \%$. The collected data were processed with the SPSS 16.0 statistical software.

The respondents were mostly managing directors (48.8\%), members of the management board $(8.7 \%)$ and directors of divisions or business functions $(25.0 \%)$. With the remaining $17.5 \%$, the respondents were the heads of different (mostly advisory) departments such as strategic controlling, accounting etc. The described structure of respondents can be regarded as very satisfactory since in most cases they should have fluently mastered the discussed topics.

2 The argument for using an adapted Hrebiniak (2005b) research instrument is that it is considered to be the most well-known instrument in strategy implementation research. Although the questionnaire was developed in the context of an established market economy (i.e. the USA) the instrument is robust enough to be implemented in other contexts as well. In addition, the Slovenian transition from being an ex-socialist Yugoslav republic to an established market economy has in many views been completed. The fact that part of our research instrument has its origins in an instrument developed in an established market economy should therefore not be a problem. 
The companies included in the sample range from micro businesses to large global players. There are $22.7 \%$ of micro companies (i.e. with up to 10 employees), $27.3 \%$ of small companies (i.e. between 11 and 50 employees), $24.4 \%$ of medium-sized companies (i.e. between 51 and 250 employees) and $25.6 \%$ of large companies (i.e. with above 250 employees) in the sample. $30.7 \%$ of companies come from the manufacturing sector, $51.6 \%$ from the service sector and $17.6 \%$ from the trading sector. $89.5 \%$ of the companies are privatelyowned, $7.0 \%$ have mixed ownership, while only $3.5 \%$ are state-owned. With regard to their sales market, $52.3 \%$ of the companies operate only in the Slovenian market, $25.0 \%$ earn some revenues abroad, while only $22.7 \%$ are mainly focused on foreign markets.

\section{Empirical findings and discussion}

\subsection{Activities for strategy implementation}

In the research we first wanted to find out how the companies rely on different activities when implementing their strategies. On a seven-point scale $(1=$ this activity plays no role in our strategy implementation; $7=$ this activity plays extremely important role in our strategy implementation), managers on average assessed planning and implementing projects (Mean $=5.75)$, allocating strict responsibility for strategy implementation (Mean $=5.51$ ), formulating and implementing development programmes (Mean $=5.47)$, using an efficient annual planning system (Mean $=5.46$ ), using leadership to direct employees (Mean $=5.24)$, organising (i.e. adapting the organisational structure to the strategy) for strategy implementation (Mean $=5.01$ ) and applying action planning (Mean $=5.01$ ) as those activities that represent the most important tools in their companies' strategy implementation. Other groups of activities were assessed as having slightly less important role, but they still received above-average scores, i.e. between 4.18 and 4.98 (see Table 3). The results show that all groups of activities identified in the literature also play important roles in the process of strategy implementation in Slovenian business practice. It is therefore impossible to eliminate any group from our list as being unimportant, although the ranking of the activities in Table 3 clearly shows that managers rely more on those activities that are part of planning and organising (which means they rely on activities similar to those prescribed by Hrebiniak and Joyce (1984) in their model) than on those that belong to leadership and controlling. The finding that in Slovenian companies controlling activities are more problematic than planning activities has also been found by Pučko and Čater (2001). A possible explanation of this is that Slovenian companies still face many behavioural problems of control, such as non-motivating compensation systems, poor co-operation among management and subordinates in the control process etc. 
Besides examining strategy implementation activities on the whole set of companies included in our sample, an ANOVA was conducted to also test whether the implementation of activities differs between companies from different size, sector, ownership and sales market groups. The results (see Table 3 ) show that only company size influences the way most activities are practiced, while the influence of sector, ownership and sales market is only significant for some activities. With regard to company size, the results were more or less expected. Namely, almost all activities are used more in medium-sized and large companies than in micro and small companies.

The results come as no surprise because larger companies possess more financial, human and other types of resources which enable them to practice strategy implementation activities that some smaller companies cannot afford. Similarly, practicing such activities like, for example, annual planning, tactical control etc. in a very systematic and formal way is probably less urgent in smaller companies than in larger ones. In addition to the general arguments for the less systematic and frequent practicing of strategy implementation activities in small companies, a possible context-specific explanation of such a finding may also be the fact that small companies in Slovenia are mostly managed by their founders/entrepreneurs with relatively limited managerial knowledge and experience (Ruzzier et al. 2007) - mostly due to limited past possibilities to acquire proper experience about how to do business in the established market economy. Besides the abovementioned problems with knowledge/experience, some other authors also report that strategy implementation activities in small companies from post-transitional economies may be hindered because of problems related to poorly developed management skills (Lloyd-Reason et al. 2005), unambitious managers'/entrepreneurs' visions and goals (Dittrich et al. 2008) and poor product quality (Neupert et al. 2006).

As for the sector differences, the results show that manufacturing companies to a greater extent than service and trading companies base their strategy implementation on formulating and implementing development programmes and using balanced scorecards. In addition, manufacturing companies also rely more on efficient annual planning systems, while action planning is obviously more important in manufacturing and trading companies than in service companies.

These results could mean that manufacturing companies (and in some cases also trading companies) due to their greater capital investments and export orientation take development programmes, annual planning, action planning and similar activities more seriously than service companies. Similar conclusions can also be reached based on research findings in other post-transitional contexts. In Eastern Germany, for example, Heyder and Theuvsen (2008) found that companies in certain manufacturing industries (i.e. food and beverage industries) have managed to build a very strong competitive position relative to their Western German counterparts. 
Table 3. activities for strategy implementation (descriptive statistics and dieferences between groups of companies

\begin{tabular}{|c|c|c|c|c|c|c|c|c|c|c|c|}
\hline \multirow{2}{*}{$\begin{array}{l}\text { Activities for } \\
\text { strategy } \\
\text { implementation }\end{array}$} & \multirow{2}{*}{ Mean } & \multirow{2}{*}{$\begin{array}{l}\text { Std. } \\
\text { dev. }\end{array}$} & \multicolumn{2}{|l|}{ Size $^{1}$} & \multicolumn{3}{|c|}{ Sector $^{2}$} & \multicolumn{2}{|c|}{ Ownership $^{3}$} & \multicolumn{2}{|c|}{ Market $^{4}$} \\
\hline & & & Small & Large & Man. & Serv. & Trad. & Priv. & State & Slov. & For. \\
\hline $\begin{array}{l}\text { Planning and } \\
\text { implementing } \\
\text { projects }\end{array}$ & 5.75 & 1.16 & $5.55^{\mathrm{a}}$ & $5.95^{\mathrm{a}}$ & & & & & & & \\
\hline $\begin{array}{l}\text { Allocating strict } \\
\text { responsibility } \\
\text { for strategy } \\
\text { implementation }\end{array}$ & 5.51 & 1.24 & $5.11^{\mathrm{c}}$ & $5.92^{\mathrm{c}}$ & & & & $5.44^{\mathrm{a}}$ & $6.50^{\mathrm{a}}$ & & \\
\hline $\begin{array}{l}\text { Formulating } \\
\text { and } \\
\text { implementing } \\
\text { development } \\
\text { programmes }\end{array}$ & 5.47 & 1.23 & $5.20^{\mathrm{b}}$ & $5.74^{\mathrm{b}}$ & $5.96^{\mathrm{b}}$ & $5.19^{\mathrm{b}}$ & $5.31^{\mathrm{b}}$ & & & $5.17^{\mathrm{b}}$ & $5.92^{\mathrm{b}}$ \\
\hline $\begin{array}{l}\text { Using an } \\
\text { efficient annual } \\
\text { planning system }\end{array}$ & 5.46 & 1.36 & $4.97^{\mathrm{c}}$ & $5.96^{\mathrm{c}}$ & $5.79^{\mathrm{a}}$ & $5.27^{\mathrm{a}}$ & & & & $5.26^{\mathrm{b}}$ & $5.95^{\mathrm{b}}$ \\
\hline $\begin{array}{l}\text { Using } \\
\text { leadership to } \\
\text { direct } \\
\text { employees }\end{array}$ & 5.24 & 1.39 & & & & & & & & & \\
\hline $\begin{array}{l}\text { Organising for } \\
\text { strategy } \\
\text { implementation }\end{array}$ & 5.01 & 1.19 & $4.71^{\mathrm{b}}$ & $5.31^{\mathrm{b}}$ & & & & & & & \\
\hline $\begin{array}{l}\text { Applying action } \\
\text { planning }\end{array}$ & 5.01 & 1.37 & $4.57^{\mathrm{c}}$ & $5.44^{\mathrm{c}}$ & $5.47^{\mathrm{b}}$ & $4.62^{\mathrm{b}}$ & $5.32^{\mathrm{b}}$ & & & & \\
\hline $\begin{array}{l}\text { Using formal } \\
\text { communication }\end{array}$ & 4.98 & 1.23 & & & & & & & & & \\
\hline $\begin{array}{l}\text { Applying HRM } \\
\text { activities }\end{array}$ & 4.85 & 1.62 & $4.26^{\mathrm{c}}$ & $5.43^{\mathrm{c}}$ & & & & & & & \\
\hline $\begin{array}{l}\text { Applying MBO } \\
\text { (management by } \\
\text { object.) }\end{array}$ & 4.82 & 1.33 & $4.50^{\mathrm{b}}$ & $5.15^{\mathrm{b}}$ & & & & & & $4.70^{\mathrm{a}}$ & $5.28^{\mathrm{a}}$ \\
\hline $\begin{array}{l}\text { Using an } \\
\text { efficient tactical } \\
\text { control system }\end{array}$ & 4.47 & 1.43 & $4.10^{\mathrm{b}}$ & $4.82^{\mathrm{b}}$ & & & & & & & \\
\hline $\begin{array}{l}\text { Applying the } \\
\text { BSC (balanced } \\
\text { scorecard) }\end{array}$ & 4.18 & 1.53 & $3.62^{\mathrm{c}}$ & $4.75^{\mathrm{c}}$ & $4.57^{\mathrm{a}}$ & $3.93^{\mathrm{a}}$ & $4.07^{\mathrm{a}}$ & & & & \\
\hline
\end{tabular}

Note: Only statistically significant differences $\left(\mathrm{p}<0.05^{(\mathrm{a})}, \mathrm{p}<0.01^{(\mathrm{b})}\right.$ and $\left.\mathrm{p}<0.001^{(\mathrm{c})}\right)$ are shown.

${ }^{(1)}$ Significant contrast: micro+small vs. medium+large companies.

${ }^{(2)}$ Significant contrasts: manufacturing vs. service companies and manufacturing vs. trading companies.

(3) Significant contrast: private vs. state-owned companies (mixed-owned companies are excluded).

(4) Significant contrast: companies oriented mainly to the Slovenian market vs. companies oriented mainly to foreign markets (companies with a mixed orientation are excluded). 
As for the effect of company ownership, allocating strict responsibility for strategy implementation seems to be more emphasised in state-owned companies than in private companies. This finding can probably be explained by the greater levels of formalisation (or even bureaucracy) usually present in larger state-owned companies, which has also been found in studies by Labroukos et al. (1995) and Singh (2004). All other activities seem to be equally important in state-owned and private companies. Finally, the effect of the prevailing sales market can be found for three activities, i.e. formulating and implementing development programmes and using annual planning and management by objectives. All three activities seem to be more popular in companies oriented to foreign markets than in companies oriented primarily to the Slovenian market. It is difficult to speculate why this is so but a possible explanation may be that developed foreign markets allow less ad-hoc decision-making and demand companies to rely more on systematic decisions based on annual planning and development programmes. Indeed, several past studies on the strategic behaviour of Slovenian companies found that an orientation to more developed (i.e. Western) markets induces similar strategic behaviour to that of companies from developed market economies (Domadenik et al. 2008), including higher market orientation (Cadez/Guilding 2008) and more Western approaches to human resources development (Zupan/Ograjenšek 2004). Similarly, in the broader post-transitional context Malovics et al. (2007) found that Hungarian companies seeking to become more "European" are more motivated to improve their development processes by, for example, paying greater respect to environmental protection. The conclusion can therefore be made that our findings provide further evidence that a company's prevailing sales market also influences its strategy implementation activities.

\subsection{Experience with the BSC in strategy implementation}

When analysing the activities on which companies rely when implementing their strategies, we did not expect to find that the use of balanced scorecards would rank last among the activities for strategy implementation. There may be several different reasons for this attitude. One reason for such a perception might be linked to the (un)familiarity and (improper) understanding of the concept as, for example, suggested by Pučko and Čater (2008). However, another reason might be the companies' past experience with the balanced scorecard. In the following paragraphs we provide a more in-depth analysis of this important strategic tool.

Our study discovers that only 33 of the $172(19.2 \%)$ companies included in the sample use the balanced scorecard to measure their performance. Companies that have experience with this system on average have used it for 4.27 years (standard deviation 2.75 years), which suggests that Slovenian business practice is still pretty much in the pioneering phase regarding application of the balanced scorecard as part of strategy implementation. Not surprisingly, companies from different groups do not use the system equally frequently. Based on the 
crosstabs and the related Chi-square analysis (see Table 4), we can conclude that differences exist in use of the balanced scorecard between companies from different size, sector, ownership and sales market groups.

Table 4. Use of the balanced scorecard (descriptive statistics and differences between groups of companies

\begin{tabular}{|l|c|c|c|c|c|c|c|c|c|c|}
\hline $\begin{array}{l}\text { Use of the } \\
\text { Balanced } \\
\text { Scorecard }\end{array}$ & \multirow{2}{*}{ Overall } & \multicolumn{2}{|c|}{ Size } & \multicolumn{3}{c|}{ Sector } & \multicolumn{2}{c|}{ Ownership } & \multicolumn{2}{c|}{ Market } \\
\cline { 3 - 10 } & Small & Large & Man. & Serv. & Trad. & Priv. & State & Slov. & For. \\
\hline $\begin{array}{l}\text { Share of } \\
\text { companies } \\
\text { using the }\end{array}$ & 19.2 & $9.3^{\mathrm{b}}$ & $29.1^{\mathrm{b}}$ & $27.7^{\mathrm{a}}$ & $10.1^{\mathrm{a}}$ & $29.6^{\mathrm{a}}$ & $17.5^{\mathrm{a}}$ & $50.0^{\mathrm{a}}$ & $13.3^{\mathrm{c}}$ & $41.0^{\mathrm{c}}$ \\
\begin{tabular}{l} 
BSC (in \%) \\
\hline $\begin{array}{l}\text { Share of } \\
\text { companies } \\
\text { not using the } \\
\text { BSC (in \%) }\end{array}$
\end{tabular} & 80.8 & $90.7^{\mathrm{b}}$ & $70.9^{\mathrm{b}}$ & $72.3^{\mathrm{a}}$ & $89.9^{\mathrm{a}}$ & $70.4^{\mathrm{a}}$ & $82.5^{\mathrm{a}}$ & $50.0^{\mathrm{a}}$ & $86.7^{\mathrm{c}}$ & $59.0^{\mathrm{c}}$ \\
\hline
\end{tabular}

Note: Only statistically significant differences $\left(\mathrm{p}<0.05^{(\mathrm{a})}, \mathrm{p}<0.01^{(\mathrm{b})}\right.$ and $\left.\mathrm{p}<0.001^{(\mathrm{c})}\right)$ are shown.

The concept is more frequently used by large companies than by small ones, more frequently by manufacturing and trading companies than by service ones, more frequently by state-owned companies than by private ones, and more frequently by companies oriented primarily to foreign markets than by companies selling primarily in the Slovenian market. These results somewhat differ from Rejc's (2004) findings that company size and prevailing sales market cannot be empirically determined as performance measurement contingencies in Slovenian companies. However, Rejc (2004) did confirm that the use of the balanced scorecard is a function of a company's corporate strategy and industry affiliation (i.e. through the power of unions and the type of technology used).

We did not ask those managers who do not use the balanced scorecard to share their experience with the system with us. Therefore, further information regarding this matter is based only on those 33 companies that did use it. Managers of these companies were asked to express their (dis)agreement $(1=$ completely disagree; 7 = completely agree) with statements describing different characteristics, consequences and potential problems with the use of the balanced scorecard. The findings of this investigation (see Table 5) reveal that managers' answers confirm the theoretical assumptions (e.g. Kaplan/Norton 2005) that the concept can only produce desirable results if it is applied in each business unit and on the level of the company as a whole (Mean $=5.45)$ and if it is supported by an appropriate reward system (Mean = 4.73) and the use of strategic maps (Mean $=4.64$ ). In a way the results also provide an answer to those critics (Heckett Group 2005; Paranjape et al. 2006) of the balanced 
scorecard who see it as being too complex and therefore less applicable in less stable business environments. Slovenian managers obviously do not share such an opinion.

Table 5. Experience with the balanced scorecard (descriptive statistics)

\begin{tabular}{|l|c|c|}
\hline Experience with the Balanced Scorecard & Mean & Std. dev. \\
\hline $\begin{array}{l}\text { The BSC should be developed for each unit and for the whole } \\
\text { company }\end{array}$ & 5.45 & 1.68 \\
\hline Application of the BSC requires changes in reward systems & 4.73 & 1.51 \\
\hline $\begin{array}{l}\text { Application of the BSC without using strategic maps does not } \\
\text { produce results }\end{array}$ & 4.64 & 1.32 \\
\hline $\begin{array}{l}\text { Application of the BSC is only suitable for more stable } \\
\text { environments }\end{array}$ & 3.55 & 1.59 \\
\hline $\begin{array}{l}\text { Managers try to avoid the quantification of objectives required by } \\
\text { the BSC }\end{array}$ & 3.48 & 1.44 \\
\hline Managers have difficulty understanding the BSC & 2.88 & 1.34 \\
\hline The BSC is too complex for our environment & 2.59 & 1.56 \\
\hline
\end{tabular}

In addition, the results also show that managers do not have major problems comprehending the system and that introduction of the system does not require such an extreme quantification of operating goals (as, for example, mentioned by Paranjape et al. (2006)) that managers would be unwilling to accept it. The above findings suggest that, although Slovenian managers do not see serious technical problems with the comprehension, introduction and implementation of the balanced scorecard, the concept's use is still very limited. A possible explanation of this may be that the construction of the balanced scorecard was based on American values (Bescos/Cauvin 2004) and as such does not pay proper respect to certain factors (e.g. the power of unions, environmental protection issues etc.) that are much more important in Europe than in the USA.

Besides examining the experience with the balanced scorecard on the whole set of companies which use the concept, an ANOVA was conducted to also test whether the experience with the concept differs between companies from different size, sector, ownership and sales market groups. Our analysis revealed no significant differences in experience with the balanced scorecard between companies from different groups, which can most probably be explained by the small sample of companies (only 33) that use the concept.

\subsection{Obstacles to strategy implementation}

Besides analysing the implementation of activities for strategy implementation, our focus was also on analysing the obstacles companies encounter when implementing their strategies. Managers were asked to use a seven-point scale (1 $=$ this obstacle did not hinder our strategy implementation at all; $7=$ this obstacle hindered our strategy implementation very much) to assess the magnitude of the obstacles their companies had been facing in the last five 
years. Interestingly, managers on average assessed an unstimulative reward system as the most relevant obstacle (Mean = 4.48). Among the other most critical obstacles managers also included weaknesses in communicating the strategy to lower organisational levels $($ Mean $=4.16)$, a lack of leadership skills among managers (Mean $=4.10$ ), a lack of ideas how to persuade employees to implement the selected strategy (Mean $=4.09$ ), a poorly defined strategy (Mean $=4.08$ ), a lack of top management's engagement in strategy implementation (4.08 points) and the domination of a short-range orientation in the company (4.05 points). All other obstacles received a below-average score, i.e. less than 4.00 points (see Table 6 ). These results show that poor leadership is the biggest problem for successful strategy implementation in Slovenian companies (the three top-ranking obstacles in Table 6 can all be classified as part of the leadership context according to Hrebiniak (2005b)). On the other hand, obstacles classified by Hrebiniak (2005b) as part of the organisational culture are seen as being the least problematic in Slovenian companies. Another interesting conclusion is observed if we compare the above results with Baier et al.'s (1988) classification of strategy implementation problems. Namely, most of the obstacles that received the highest scores relate primarily to Baier et al.'s bureaucratic or technical difficulties (including those related with improper leadership/managerial knowledge and skills). Inversely, Baier et al.'s interpersonal difficulties seem to play a much less important role. The problem that strategy implementers can be "self-interested actors" who "evade control" (Baier et al. 1988:151) therefore cannot be seen as a common interpretation of strategy implementation problems in Slovenian companies. It is difficult to say why this is so but a possible reason for this may be that many of today's employees were still trained in the former socialist business environment. The same rationale may also be used to assert why bureaucratic or technical difficulties are more relevant in Slovenian business practice.

For some of the obstacles to strategy implementation our results can be described as more or less expected. Namely, obstacles that were also recognised as relatively more problematic in other post-transitional studies are, for example, limited leadership skills (Lloyd-Reason et al. 2005) and especially companies' short-term orientation (Manolova/Yan 2002; Grachev/Izyumov 2003; Zupan/Ograjenšek 2004). On the other hand, some of our findings are quite different from those found in previous post-transitional studies. Lukasova (2004), for instance, reports that in the Czech Republic many problems in strategy implementation have their source in the weak and diffuse organisational cultures of companies. In our study, variables related to organisational culture were not found to be very problematic. One such variable is, for example, the employees' reluctance to share knowledge with others. In comparison with previous studies (Ipe 2003; Michailova/Husted 2004; Wang 2004; Hutchings/Michailova 2006) which found that employee knowledge sharing is quite limited and tends to decrease with increasing competition for work 
performance, our results indicate a surprisingly low magnitude of this problem. Although this could mean that information and knowledge flow is not a serious problem in Slovenian business practice, we doubt the adequacy of such top managers' perceptions. This doubt is even greater if we consider the high standard deviation for this item which tells us that managers are not very unified in assessing the importance of the lack of knowledge sharing in hindering strategy implementation.

Although a comparison with studies in similar post-transitional contexts are more interesting, our results can be compared in a most direct way (due to the similar measurement instrument used) with the results of Wharton-Gartner's (Hrebiniak 2005b) American-based study. The comparison reveals big differences in the importance attributed to several obstacles to strategy implementation. The obstacles found to be relatively more important in our study than in the American context are especially the unstimulative reward system and the lack of top management's engagement in strategy implementation (ranked only ninth and twelfth, respectively, in the American study). On the other hand, the lack of capabilities for implementing change management is ranked first among the obstacles in the American context, while it is only ranked eighth in our study. The importance of some other obstacles, i.e. weaknesses in communicating the strategy to lower levels, a poorly defined strategy and a lack of ideas on how to persuade employees to execute the selected strategy, is assessed similarly in both studies.

Similarly as for the analysis of the activities we also used an ANOVA to test whether there are differences between companies from different size, sector, ownership and sales market groups in terms of obstacles that companies encounter when implementing their strategies. In comparison with the differences in the implementation of activities, the results for the obstacles (see Table 6) show almost no significant differences between the analysed groups of companies. The differences that were found relate only to the poor communication of strategies to the lower hierarchical levels and a lack of capabilities to introduce changes, which seem to play a more important role in hindering strategy implementation in medium-sized and large companies than in micro and small companies. The reasons for these differences are probably linked with the fact that large companies have more complex organisational structures which, in turn, create greater problems in communication processes as well as in the persuasion of employees to accept changes. These problems are therefore probably more a consequence of bureaucratic or technical factors than they are a consequence of interpersonal factors. With regard to the other three characteristics of a company, i.e. sector (manufacturing vs. service vs. trading companies), ownership (private vs. state-owned companies) and sales market (Slovenian vs. foreign markets), no significant differences were found in the presence of obstacles to strategy implementation. 
Table 6. Obstacles to strategy implementation (descriptive statistics and differences between groups of companies)

\begin{tabular}{|c|c|c|c|c|}
\hline \multirow{2}{*}{ Obstacles to strategy implementation } & \multirow{2}{*}{ Mean } & \multirow{2}{*}{$\begin{array}{l}\text { Std. } \\
\text { dev. }\end{array}$} & \multicolumn{2}{|c|}{ Size $^{1}$} \\
\hline & & & Small & Large \\
\hline $\begin{array}{l}\text { Reward systems do not stimulate } \\
\text { implementation }\end{array}$ & 4.48 & 1.67 & & \\
\hline Strategy is not properly communicated to lower levels & 4.16 & 1.74 & $3.90^{\mathrm{a}}$ & $4.41^{\mathrm{a}}$ \\
\hline $\begin{array}{l}\text { Managers lack leadership skills for strategy } \\
\text { implementation }\end{array}$ & 4.10 & 1.87 & & \\
\hline $\begin{array}{l}\text { Managers lack ideas how to persuade employees to } \\
\text { execute the strategy }\end{array}$ & 4.09 & 1.64 & & \\
\hline Strategy is poorly defined & 4.08 & 1.85 & & \\
\hline $\begin{array}{l}\text { Top management is not actively engaged in strategy } \\
\text { implementation }\end{array}$ & 4.08 & 1.76 & & \\
\hline Short-range orientation dominates the company & 4.05 & 1.64 & & \\
\hline $\begin{array}{l}\text { Managers lack capabilities to implement change } \\
\text { management }\end{array}$ & 3.97 & 1.79 & $3.70^{\mathrm{a}}$ & $4.24^{\mathrm{a}}$ \\
\hline $\begin{array}{l}\text { Strategy conflicts with existing organisational power } \\
\text { structure }\end{array}$ & 3.96 & 1.71 & & \\
\hline Strategic analysis is not properly conducted & 3.93 & 1.39 & & \\
\hline $\begin{array}{l}\text { There are no guidelines or a model to guide strategy } \\
\text { execution efforts }\end{array}$ & 3.42 & 1.53 & & \\
\hline $\begin{array}{l}\text { Employees are reluctant to share knowledge with } \\
\text { colleagues }\end{array}$ & 3.24 & 1.77 & & \\
\hline $\begin{array}{l}\text { Managers do not trust information generated outside } \\
\text { their units }\end{array}$ & 3.10 & 1.62 & & \\
\hline
\end{tabular}

Note: $\quad$ Only statistically significant differences $\left(\mathrm{p}<0.05^{(\mathrm{a})}\right)$ are shown.

(1) Significant contrast: micro+small vs. medium+large companies.

The assessments of the most important obstacles to strategy implementation in Slovenian business practice show lower average scores than the assessments of the most important activities for strategy implementation. On the other side, the standard deviations (see Tables 3 and 6) are greater when assessing the obstacles. This might mean that Slovenian managers are less aware of the obstacles to than they are of the activities for successful strategy implementation.

\subsection{Strategy implementation and company performance}

The last part of our study focuses on analysing the links between the activities for strategy implementation and obstacles to strategy implementation on one hand, and company performance on the other. The relationships among these variables are first analysed by using bivariate Pearson correlation coefficients. The results show that not all activities and obstacles are significantly linked with 
performance. In Table 7 we present only those activities and obstacles for which significant (positive or negative) correlations with ROE could be found..

Table 7. Bivariate correlations among activities for strategy implementation obstacles to strategy implementation and company performance (ROE)

\begin{tabular}{|c|c|c|c|c|c|c|c|c|}
\hline Variables & ROE & A1 & A2 & $\mathrm{O} 1$ & $\mathrm{O} 2$ & $\mathrm{O} 3$ & $\mathrm{O} 4$ & $\mathrm{O5}$ \\
\hline ROE & $\begin{array}{l}1.000 \\
(0.000)\end{array}$ & & & & & & & \\
\hline $\begin{array}{l}\text { A1: Organising for } \\
\text { strategy implementation }\end{array}$ & $\begin{array}{l}0.220 \\
(0.004)\end{array}$ & $\begin{array}{l}1.000 \\
(0.000)\end{array}$ & & & & & & \\
\hline $\begin{array}{l}\text { A2: Allocating strict } \\
\text { responsibility for strategy } \\
\text { implementation }\end{array}$ & $\begin{array}{l}0.168 \\
(0.030)\end{array}$ & $\begin{array}{l}0.570 \\
(0.000)\end{array}$ & $\begin{array}{l}1.000 \\
(0.000)\end{array}$ & & & & & \\
\hline $\begin{array}{l}\mathrm{O} 1: \text { Employees are } \\
\text { reluctant to share } \\
\text { knowledge with colleagues }\end{array}$ & $\begin{array}{l}-0.411 \\
(0.000)\end{array}$ & $\begin{array}{l}-0.066 \\
(0.395)\end{array}$ & $\begin{array}{l}-0.165 \\
(0.033)\end{array}$ & $\begin{array}{l}1.000 \\
(0.000)\end{array}$ & & & & \\
\hline $\begin{array}{l}\text { O2: Managers lack } \\
\text { leadership skills for } \\
\text { strategy implementation }\end{array}$ & $\begin{array}{l}-0.366 \\
(0.000)\end{array}$ & $\begin{array}{l}0.008 \\
(0.914)\end{array}$ & $\begin{array}{l}0.047 \\
(0.555)\end{array}$ & $\begin{array}{l}0.330 \\
(0.000)\end{array}$ & $\begin{array}{l}1.000 \\
(0.000)\end{array}$ & & & \\
\hline $\begin{array}{l}\text { O3: Managers lack } \\
\text { capabilities to implement } \\
\text { change management }\end{array}$ & $\begin{array}{l}-0.297 \\
(0.000)\end{array}$ & $\begin{array}{l}0.098 \\
(0.214)\end{array}$ & $\begin{array}{l}0.065 \\
(0.414)\end{array}$ & $\begin{array}{l}0.422 \\
(0.000)\end{array}$ & $\begin{array}{l}0.672 \\
(0.000)\end{array}$ & $\begin{array}{l}1.000 \\
(0.000)\end{array}$ & & \\
\hline $\begin{array}{l}\text { O4: Strategy is poorly } \\
\text { defined }\end{array}$ & $\begin{array}{l}-0.192 \\
(0.013)\end{array}$ & \begin{tabular}{|l|}
0.115 \\
$(0.138)$
\end{tabular} & $\begin{array}{l}0.027 \\
(0.736)\end{array}$ & $\begin{array}{l}0.249 \\
(0.001)\end{array}$ & $\begin{array}{l}0.610 \\
(0.000)\end{array}$ & \begin{tabular}{|l|}
0.506 \\
$(0.000)$
\end{tabular} & $\begin{array}{l}1.000 \\
(0.000)\end{array}$ & \\
\hline $\begin{array}{l}\text { O5: Short-range } \\
\text { orientation dominates the } \\
\text { company }\end{array}$ & $\begin{array}{l}-0.166 \\
(0.031)\end{array}$ & $\begin{array}{l}-0.107 \\
(0.168)\end{array}$ & $\begin{array}{l}-0.006 \\
(0.938)\end{array}$ & $\begin{array}{l}0.085 \\
(0.268)\end{array}$ & $\begin{array}{l}0.429 \\
(0.000)\end{array}$ & $\begin{array}{l}0.253 \\
(0.001)\end{array}$ & $\begin{array}{l}0.381 \\
(0.000)\end{array}$ & $\begin{array}{l}1.000 \\
(0.000)\end{array}$ \\
\hline
\end{tabular}

Note: Only those activities $\left(\mathrm{A}_{1}\right.$ and $\left.\mathrm{A}_{2}\right)$ and obstacles $\left(\mathrm{O}_{1}\right.$ to $\left.\mathrm{O}_{5}\right)$ are shown which have statistically significant $(\mathrm{p}<0.05)$ Pearson correlation coefficients with ROE.

Unsurprisingly, executing certain activities for strategy implementation is positively linked with performance, while experiencing obstacles to strategy implementation is negatively linked with performance. The activities that are positively correlated with performance are adapting the organisational structure to the strategy $(\mathrm{R}=0.220)$ and allocating strict responsibility for strategy implementation $(\mathrm{R}=0.168)$, whereas the obstacles with a negative correlation with performance are employees' reluctance to share knowledge with colleagues $(\mathrm{R}=-0.411)$, a lack of managers' leadership skills $(\mathrm{R}=-0.366)$, a lack of managers' capabilities to implement change management $(\mathrm{R}=-0.297)$, a poorly defined strategy $(\mathrm{R}=-0.192)$ and the company's short-range orientation $(\mathrm{R}=$ 0.166). Based on the above variables that are correlated with performance we can conclude that, among the activities for strategy implementation, only organising activities are linked with performance while, among the obstacles to strategy implementation, four out of the five analysed types of obstacles (problems with change management, organisational culture, organisational power structure and leadership) are linked with performance. The literature offers relatively limited possibilities to compare the above results with the 
results of similar studies. Although the importance of variables such as knowledge sharing (Michailova/Husted 2004; Hutchings/Michailova 2006; Škerlavaj et al. 2007; Hernaus et al. 2008), leadership skills (Lloyd-Reason et al. 2005; Zagoršek et al. 2009), skills for implementing changes (Domadenik et al. 2008) and a short-term orientation (Manolova/Yan 2002; Grachev/Izyumov 2003; Zupan/Ograjenšek 2004) for company performance can be found in past studies, these results unfortunately cannot be fully and directly compared with our results because they focus on different sets of variables and use different methodology.

The correlation analysis therefore enabled us to extract two activities (out of the 12 analysed) and five obstacles (out of the 13 analysed) that are significantly correlated with performance. In the next step we performed a multiple regression analysis to test how these seven variables representing activities for strategy implementation and obstacles to strategy implementation (independent variables) influence company performance (dependent variable). A stepwise method was used for the inclusion of independent variables in the model. In step one, the lack of managers' leadership skills (X1) was included, in step two the employees' reluctance to share knowledge with colleagues (X2) was included, while in step three the adaptation of organisational structure to the strategy (X3) entered the model. The final regression model $(\mathrm{ROE}=10.19-0.92 \times \mathrm{X} 1-$ $0.96 \times \mathrm{X} 2+0.98 \times \mathrm{X} 3$ ) (also see Table 8 ), in which all statistical coefficients are significant $(\mathrm{p}<0.001)$, is able to explain $21.0 \%$ of the variance of ROE $(\mathrm{R} 2=$ 0.225 ; adjusted $\mathrm{R} 2=0.210 ; \mathrm{F}=14.705 ; \mathrm{p}<0.001)$. The results show that greater obstacles to strategy implementation in the forms of inadequate leadership skills and employees' reluctance to share their knowledge have a negative influence on ROE, while adapting organisational structure to the selected strategy has a positive influence on ROE. In other words, company performance depends on proper organising activities, as well as a suitable leadership and organisational culture that supports knowledge sharing. We cannot say that the above results come as a big surprise given that these variables are seen as extremely important factors of company performance in the strategic-management-related literature (Lorange 1982; Hrebiniak/Joyce 1984; Hrebiniak 2005b; Wheelen/Hunger 2006).

As for the independent variables that are not included in the final model despite their significant correlations with performance, we can conclude that their exclusion is a combination of two factors: relatively weaker correlations with ROE (compared to those independent variables that are in the model) and/or high correlations with at least one of the independent variables that are included in the model. Allocating strict responsibility for strategy implementation was therefore not included because of its high correlation with the adaptation of organisational structure to the strategy, while the lack of managers' capabilities to implement change management, a poorly defined strategy and the company's 
short-range orientation were not included because of their relatively high correlations with a lack of managers' leadership skills for strategy implementation. Although only three variables are included in our regression model, our findings represent an important contribution to studying causalconsecutive links in the process of strategy implementation in the Slovenian business environment.

Table 8. Multiple regression for company performance (ROE)

\begin{tabular}{|c|c|c|c|c|c|}
\hline \multirow{2}{*}{ Independent variables } & \multicolumn{2}{|c|}{ Unstand. coef. } & \multirow{2}{*}{$\begin{array}{c}\text { Stand. } \\
\text { coef. }\end{array}$} & \multirow{2}{*}{$\mathrm{t}$} & \multirow{2}{*}{ Sig. } \\
\hline & $\mathrm{B}$ & $\begin{array}{l}\text { Std. } \\
\text { error }\end{array}$ & & & \\
\hline (Constant) & 10.185 & 2.344 & & 4.346 & 0.000 \\
\hline $\begin{array}{l}\text { Managers lack leadership skills for strategy } \\
\text { implementation }\end{array}$ & -0.919 & 0.255 & -0.272 & -3.597 & 0.000 \\
\hline $\begin{array}{l}\text { Employees are reluctant to share knowledge with } \\
\text { colleagues }\end{array}$ & -0.958 & 0.278 & -0.261 & -3.450 & 0.001 \\
\hline Organising for strategy implementation & 0.978 & 0.395 & -0.177 & 2.476 & 0.014 \\
\hline
\end{tabular}

\section{Conclusion and implications}

The purpose of this paper was to add to the body of knowledge on strategy implementation by studying the activities for strategy implementation and obstacles to strategy implementation faced by Slovenian companies. Our first research question dealt with an analysis of the most important groups of activities for and obstacles to strategy implementation. The results show that all groups of activities identified in the literature received above-average scores, which means they also play important roles in the process of strategy implementation in Slovenian business practice. Nevertheless, we can see that managers on average believe that planning and implementing projects, allocating strict responsibility for strategy implementation, formulating and implementing development programmes and using an efficient annual planning system are the most important groups of activities for successful strategy implementation. In other words, Slovenian managers obviously favour planning and organising activities when implementing their company's strategies, which provides some kind of support for Hrebiniak and Joyce's (1984) model. Although all strategy implementation activities were assessed as important, the ranks of some of them are quite a surprise. The use of balanced scorecards, for example, is ranked last although it has received considerable attention in the literature. The reason for this may be linked to the (un)familiarity and (improper) understanding of the concept or, alternatively, to the companies' past experience with implementing balanced scorecards. On the other hand, the analysis of the obstacles to strategy implementation reveals that managers on average assess an unstimulative reward system as the most relevant obstacle. 
Among the other common obstacles, managers also include weaknesses in communicating the strategy, a lack of leadership skills, a poorly defined strategy, a lack of top management's engagement and the domination of a shortrange orientation in a company, while all other analysed obstacles received a below-average score.

A comparison of our results with the results of past studies in post-transitional contexts (Manolova/Yan 2002; Grachev/Izyumov 2003; Lukasova 2004; Zupan/Ograjenšek 2004; Lloyd-Reason et al. 2005) reveals a similarity in the perception of poor leadership skills and a short-term orientation as very important obstacles to strategy implementation, while organisational-culturerelated obstacles, which are also emphasised as a problem in some posttransitional contexts, are not perceived as very problematic by Slovenian managers. In this respect, Slovenian managers have a similar perception as American managers (Hrebiniak 2005b) who also do not encounter big organisational-culture-related problems when executing their company's strategies. In spite of this similarity, a comparison of our results with the results of Wharton-Gartner's American-based study reveals some considerable differences in managers' perceptions. Namely, American managers see bigger obstacles in change management and power-structure-related issues, while Slovenian managers, similarly as in some other post-transitional contexts, obviously perceive obstacles related to poor leadership as being much more present. This could mean that post-transitional managers after their country's transition period are still not managing to fully conquer all the leadership techniques required for to effectively implement strategy. We can conclude that the most relevant problems of strategy implementation in Slovenian business practice can be classified as bureaucratic or technical (including skills-related) difficulties according to Baier et al.'s (1988) classification. Similar conclusions can also be found in some other post-transitional studies in which authors argue that companies' strategy implementation is hindered by such bureaucratic/ technical difficulties as bureaucratic business cultures (Grachev/Izyumov 2003), problems of financing a company's growth (Hutchinson/Xavier 2006) and even poor legal environments (Nieminen et al. 2001).

Our second research question investigated how companies from different size, sector, ownership and sales market groups differ in the activities they practice and in the obstacles they face when implementing their strategies. The findings indicate that only company size influences the way most activities are practiced, while the influence of sector, ownership and sales market is only significant for some activities. The size-related differences show that almost all activities are used more in medium-sized and large companies than in micro and small companies. As larger companies possess more financial, human and other types of resources, which enable them to practice activities that some smaller companies cannot afford, the results are more or less expected. With regard to 
the use of the balanced scorecard, we found that Slovenian business practice is still pretty much in the pioneering phase regarding application of the concept. As expected, companies from different groups do not use the system equally frequently. The concept is more frequently used by large companies than by small ones, more frequently by manufacturing and trading companies than by service ones, more frequently by state-owned companies than by private ones, and more frequently by companies oriented primarily to foreign markets than by companies selling primarily in the Slovenian market. In comparison with the differences in the implementation of activities, the results for the obstacles show almost no significant differences between the analysed groups of companies. This means that organisational contexts, such as change management, cultural, power structure and leadership context, can play an important role in hindering the strategy implementation regardless of the type of company.

Finally, our third research question dealt with the relationship between the activities for and obstacles to strategy implementation on one hand and company performance on the other. The results show that greater obstacles to strategy implementation in the forms of inadequate leadership skills and employees' reluctance to share their knowledge have a negative influence on ROE, while adapting the organisational structure to the selected strategy as an activity for strategy implementation has a positive influence on ROE. In other words, company performance depends on proper organising activities, as well as a suitable leadership and organisational culture which supports knowledge sharing. Although only three independent variables are included in the final multiple regression model, the results still indicate that certain activities for strategy implementation positively influence company performance, while certain obstacles to strategy implementation have a negative impact on company performance. The results are therefore in line with some previous findings (e.g. Alexander 1985; Pellegrinelli/Bowman 1994; Al-Ghamdi 1998; Parsa 1999; Raps 2004; Brenes et al. 2008) that the successful execution of strategy implementation activities and careful avoidance of strategy implementation obstacles do pay.

\section{Managerial implications}

We believe that, along with theoretical implications, our study also provides some important implications for managers. The first practical implication relates to our finding that practicing strategy implementation activities is important and can bring positive results to a company. Well-crafted strategies are worthless unless they are effectively implemented. It is better to have a less perfectly crafted strategy which is fully executed than to formulate an excellent strategy which is never implemented. Therefore, instead of investing large sums of money in strategic planning only, companies obviously need to improve their strategy implementation as well. The need for a balance between strategic planning activities and strategy implementation activities was perhaps best 
described by Giles (1991:75): "If it were possible for an entire organisation to sing the same song from the same song sheet and face in the same direction at the same time, that would be a powerful force. If the song was good, the direction true and the timing right, it would be a very serious threat to competitors." The quality of the song (strategic plan) and the quality of the singing (strategy execution) therefore need to be properly balanced. It is only when managers correctly perceive the importance of the execution as a whole that they can properly allocate limited resources to individual strategy implementation activities. Slovenian managers, for example, seem to properly understand the importance of planning and organising activities, while the same cannot be said for leadership and controlling activities. From this perspective, our results can therefore assist emergent market managers in better allocating resources among different activities so as to successfully implement the selected strategies.

While the execution of the identified activities is important, our results suggest that company performance depends even more on successfully avoiding contextual obstacles to strategy implementation. Many of these obstacles may have a considerable negative impact on strategy execution unless the execution is disciplined. The "discipline" is required because the responsibility for strategy execution rests on a broader structure of employees, not only on top management. The execution therefore involves more people than planning which necessarily calls for the right leadership, a suitable organisational culture, persuading employees to accept changes and executing strategies in a way that does not conflict with the existing power structure. As our results indicate, Slovenian managers may underestimate the importance of some contextual variables such as knowledge sharing and change management. Although both of these obstacles have a considerable influence on company performance, they were assessed by the managers with below-average scores. Our findings can therefore be used by management as a kind of signal of the most important barriers in the company that are hindering successful strategy implementation.

\section{Contributions, limitations and suggestions for future research}

The study represents a comprehensive and systematic approach to studying activities for and obstacles to strategy implementation. While there are not many such studies in established market economies, there is an even greater lack of such studies in post-transitional contexts. Our research findings therefore not only offer an overview of the relevance of the studied activities for and obstacles to strategy implementation but also broaden the scope of empirical research by performing the study in the post-transitional context. In this respect, our study can serve as a tool for enhancing the generalisability and validity of the measurement instrument and the theory on strategy implementation developed in more "Western" contexts. Irrespective of some important findings of this research, its possible weaknesses should also be mentioned. One such limitation 
lies in the fact that real obstacles to strategy implementation might be well hidden even to a company's management. Therefore, the managers' assessments given when answering our questionnaire are necessarily subjective. We are also well aware that our findings are based on a single sample of companies from one (small) post-transitional economy. Over three-quarters of the studied companies primarily depend on the Slovenian market, meaning they are not predominantly exposed to the competitive forces of international markets. This means that our results may not be relevant to the business practice conditions in other environmental settings. At least those few stated potential weaknesses of this study might suggest directions for future research endeavours in this field. Clearly, future research should provide cross-validation with the same instruments and other samples (in transitional, post-transitional and established market economies) to validate our findings beyond the sample used in this study.

\section{References}

Alexander, L.D. (1985): Successfully implementing strategic decisions, in: Long Range Planning, 18, 3, 91-97.

Al-Ghamdi, S.M. (1998): Obstacles to successful implementation of strategic decisions: The British experience, in: European Business Review, 98, 6, 322-327.

Baier, V.E./March, J.G./Saetren, H. (1988): Implementation and ambiguity, in: March, J.G. (ed.): Decisions and organizations, Oxford: Basil Blackwell, 150-164.

Bescos, P.-L./Cauvin, E. (2004): Performance measurement in French companies: An empirical study, in: Epstein, M.J./Manzoni, J.-F. (ed.): Performance measurement and management control: Superior organizational performance, Amsterdam: Elsevier, 185202.

Birnbaum, B. (2007): Strategy implementation: Six supporting factors, www.birnbaumassociates.com/strategy-implementation.htm, 26.10.2007.

Bourgeois, L.J. III/Brodwin, D.R. (1984): Strategic implementation: Five approaches to an elusive phenomenon, in: Strategic Management Journal, 5, 3, 241-264.

Brenes, E.R./Mena, M./Molina, G.E. (2008): Key success factors for strategy implementation in Latin America, in: Journal of Business Research, 61, 6, 590-598.

Cadez, S./Guilding, C. (2008): An exploratory investigation of an integrated contingency model of strategic management accounting, in: Accounting, Organizations and Society, 33, 7-8, 836-863.

Connor, T. (2001): Product levels as an aid to functional strategy development, in: Strategic Change, 10, 4, 223-237.

Crittenden, V.L./Crittenden, W.F. (2008): Building a capable organization: The eight levers of strategy implementation, in: Business Horizons, 51, 4, 301-309.

Dittrich, E./Schrader, H./Stojanov, C. (2008): The development of small enterprises in Bulgaria, Czech Republic and the Russian Federation, in: Journal for East European Management Studies, 13, 2, 129-153. 
Domadenik, P./Prašnikar, J./Svejnar, J. (2008): Restructuring of firms in transition: Ownership, institutions and openness to trade, in: Journal of International Business Studies, 39, 4, 725-746.

Farsight Leadership Organisation (2007): Strategy implementation and realisation, www.businessballs.com/businessstrategyimplementation.htm, 24.10.2007.

Fulmer, W.E. (1990): Human resource management: The right hand of strategy implementation, in: Human Resource Planning, 13, 1, 1-11.

Giles, W.D. (1991): Making strategy work, in: Long Range Planning, 24, 5, 75-91.

Gottschalk, P. (2008): Organizational structure as predictor of intelligence strategy implementation in policing, in: International Journal of Law, Crime and Justice, 36, 3, 184-195.

Grachev, M./Izyumov, A. (2003): Development of business culture in a newly market economy, in: Journal of East-West Business, 9, 2, 7-28.

Grundy, T. (1998): Strategy implementation and project management, in: International Journal of Project Management, 16, 1, 43-50.

Gurkov, I. (2009): Strategy process as formulation and realization of corporate goals: The synthesis of surveys in Russian firms, in: Journal for East European Management Studies, 14, 1, 48-64.

Gurowitz, E.M. (2007): The challenge of strategy implementation, www.gurowitz.com/ articles/strategy.pdf, 26.10.2007.

Hambrick, D.C./Cannella, A.A. Jr. (1989): Strategy implementation as substance and selling, in: Academy of Management Executive, 3, 4, 278-285.

Hauc, A./Kovač, J. (2000): Project management in strategy implementation: Experiences in Slovenia, in: International Journal of Project Management, 18, 1, 61-67.

Heckett Group (2005): Most executives are unable to take balanced scorecards from concept to reality, in: Perspectives on Performance, $4,1,3$.

Heintz, M. (2002): East European managers and Western management theories: An ethnographic approach of Romanian service sector enterprises, in: Journal for East European Management Studies, 7, 3, 279-297.

Hernaus, T./Škerlavaj, M./Dimovski, V. (2008): Relationship between organisational learning and organisational performance: The case of Croatia, in: Transformations in Business and Economics, 7, 2, 32-48.

Heyder, M./Theuvsen, L. (2008): Strategic management in the German brewing industry: Are there still differences between East and West?, in: Journal for East European Management Studies, 13, 1, 10-39.

Higgins, J.M. (2005): The eight 'S's of successful strategy execution, in: Journal of Change Management, 5, 1, 3-13.

Hrebiniak, L.G. (2005a): A strategic look at strategy execution, in: Optimize, 4, 3, 57-59.

Hrebiniak, L.G. (2005b): Making strategy work: Leading effective execution and change. Upper Saddle River: Pearson Education.

Hrebiniak, L.G. (2006): Obstacles to effective strategy implementation, in: Organizational Dynamics, 35, 1, 12-31. 
Hrebiniak, L.G. (2008): Making strategy work: Overcoming the obstacles to effective execution, in: Ivey Business Journal Online, 72, 2, 1.

Hrebiniak, L.G./Joyce, W.F. (1984): Implementing strategy. New York: Macmillan Publishing.

Hutchings, K./Michailova, S. (2006): The impact of group membership on knowledge sharing in Russia and China, in: International Journal of Emerging Markets, 1, 1, 21-34.

Hutchinson, J./Xavier, A. (2006): Comparing the impact of credit constraints on the growth of SMEs in a transition country with an established market economy, in: Small Business Economics, 27, 2-3, 169-179.

Ipe, M. (2003): Knowledge sharing on organizations: A conceptual framework, in: Human Resource Development Review, 2, 4, 337-359.

Judson, A.S. (1991): Invest in a high-yield strategic plan, in: Journal of Business Strategy, 12, 4, 34-39.

Kaplan, R.S./Norton, D.P. (1996): The balanced scorecard: Translating strategy into action. Boston: Harvard Business School Press.

Kaplan, R.S./Norton, D.P. (2005): The office of strategy management, in: Harvard Business Review, 83, 10, 72-80.

Kaplan, R.S./Norton, D.P. (2006): How to implement a new strategy without disrupting your organization, in: Harvard Business Review, 84, 3, 100-109.

Kovač, J. (1996): Povečanje učinkovitosti uresničevanja strategije podjetja s pomočjo projektnega managementa, in: Organizacija, 29, 2, 94-99.

Labroukos, N.S./Lioukas, S./Chambers, D. (1995): Planning and performance in state-owned enterprises: A multidimensional assessment, in: European Journal of Operational Research, 87, 3, 624-640.

Lloyd-Reason (ed.) (2005): Internationalisation process, SMEs and transitional economies: A four-country perspective, in: International Journal of Entrepreneurship and Innovation Management, 5, 3-4, 206-226.

Lorange, P. (1982): Implementation of strategic planning. Englewood Cliffs: Prentice Hall.

Lukasova, R. (2004): Strategic aspects of organizational culture of Czech companies, in: Journal of East-West Business, 10, 1, 93-104.

Malovics, G./Racz, G./Kraus, S. (2007): The role of environmental management systems in Hungary - Theoretical and empirical insights, in: Journal for East European management studies, 12, 3, 180-204.

Mankins, M.C./Steele, R. (2005): Turning strategy into great performance, in: Harvard Business Review, 83, 7-8, 64-72.

Manolova, T.S./Yan, A. (2002): Institutional constraints and entrepreneurial responses in a transforming economy: The case of Bulgaria, in: International Small Business Journal, $20,2,163-184$.

Michailova, S./Husted, K. (2004): Decision making in organisations hostile to knowledge sharing, in: Journal for East European Management Studies, 9, 1, 7-19. 
Minarro-Viseras, E./Baines, T./Sweeney, M. (2005): Key success factors when implementing strategic manufacturing initiatives, in: International Journal of Operations \& Production Management, 25, 2, 151-179.

Neupert, K.E./Baughn, C.C./Dao, T.T.L. (2006): SME exporting challenges in transitional and developed economies, in: Journal of Small Business and Enterprise Development, $13,4,535-545$.

Nicholls, J. (1994): The strategic leadership star: A guiding light in delivering value to the customer, in: Management Decision, 32, 8, 21-26.

Nieminen, J./Larimo, J./Springer, R. (2001): Market strategies and performance of Western firms in Eastern Europe: A comparative survey, in: Journal of East-West Business, 7, 3, 91-117.

Noble, C.H. (1999): The eclectic roots of strategy implementation research, in: Journal of Business Research, 45, 2, 119-134.

Paranjape, B./Rossiter, M./Pantano, V. (2006): Performance measurement systems: Successes, failures and future - a review, in: Measuring Business Excellence, 10, 3, 414.

Parsa, H.G. (1999): Interaction of strategy implementation and power perceptions in franchise systems: An empirical investigation, in: Journal of Business Research, 45, 2, 173-185.

Pellegrinelli, S./Bowman, C. (1994): Implementing strategy through projects, in: Long Range Planning, 27, 4, 125-132.

Pučko, D./Čater, T. (2001): Business annual planning and controlling in Slovenian managerial practice, in: Journal for East European Management Studies, 6, 4, 355-375.

Pučko, D. (2006): Strateško upravljanje. Ljubljana: Ekonomska fakulteta.

Pučko, D./Čater, T. (2008): What effective strategy implementation depends on: The experience of Slovenian companies, in: An Enterprise Odyssey: Tourism Governance and Entrepreneurship: 4th International Conference. Zagreb: Graduate School of Economics and Business, 1220-1234.

Raps, A. (2004): Implementing strategy, in: Strategic Finance, 85, 12, 48-53.

Rejc, A. (2004): Toward contingency theory of performance measurement, in: Journal for East European Management Studies, 9, 3, 243-264.

Ruzzier, M.(ed.) (2007): Human capital and SME internationalization: A structural equation modeling study, in: Canadian Journal of Administrative Sciences, 24, 1, 15-29.

Singh, S.P. (2004): Effect of ownership restructuring and intensity of competition on strategy and structure of state-owned enterprises: An integrated framework, in: Global Journal of Flexible Systems Management, 5, 4, 41-52.

Škerlavaj, M. (ed. (2007): Organizational learning culture: The missing link between business process change and organizational performance, in: International Journal of Production Economics, 106, 2, 346-367.

Skivington, J.E./Daft, R.L. (1991): A study of organizational "framework" and "process" modalities for the implementation of business-level strategic decisions, in: Journal of Management Studies, 28, 1, 45-68.

Speculand, R. (2006): The great big strategy challenge, in: Strategic Direction, 22, 3, 3-5. 
Terborg, J.R./Ungson, G.R. (1985): Group-administered bonus pay and retail store performance: A two-year study of management compensation, in: Journal of Retailing, $61,1,63-77$.

Ulrich, D. (1998): A new mandate for human resources, in: Harvard Business Review, 76, 1, 124-134.

Wang, C.-C. (2004): The influence of ethical and self-interest concerns on knowledge sharing intentions among managers: An empirical study, in: International Journal of Management, 21, 3, 370-381.

Wheelen, T.L./Hunger, D.J. (2006): Concepts in strategic management and business policy. Upper Saddle River: Pearson - Prentice Hall.

Zagoršek, H./Dimovski, V./Škerlavaj, M. (2009): Transactional and transformational leadership impacts on organizational learning, in: Journal for East European Management Studies, 14, 2, 144-165.

Zupan, N./Ograjenšek, I. (2004): The link between human resource management and company performance, in: Journal of East-West Business, 10, 1, 105-119. 